\title{
A combined triggering-propagation modeling approach for the assessment of rainfall induced debris flow susceptibility
}

\author{
Laura Maria Stancanelli ${ }^{\mathrm{a}, *}$, David Johnny Peres $^{\mathrm{a}}$, Antonino Cancelliere ${ }^{\mathrm{a}}$, \\ Enrico Foti ${ }^{\mathrm{a}}$ \\ ${ }^{a}$ Department of Civil Engineering and Architecture. University of Catania, Catania, Italy
}

\begin{abstract}
Rainfall-induced shallow slides can evolve into debris flows that move rapidly downstream with devastating consequences. Mapping the susceptibility to debris flow is an important aid for risk mitigation. We propose a novel practical approach to derive debris flow inundation maps useful for susceptibility assessment, that is based on the integrated use of DEM-based spatially-distributed hydrological and slope stability models with debris flow propagation models. More specifically, the TRIGRS infiltration and infinite slope stability model and the FLO-2D model for the simulation of the related debris flow propagation and deposition are combined. An empirical instability-to-debris flow triggering threshold calibrated on the basis of observed events, is applied to link the two models and to accomplish the task of determining the amount of unstable mass that develops as a debris flow. Calibration of the proposed methodology is carried out based on real data of the debris flow event occurred on 1 October 2009, in the Peloritani mountains area (Italy). Model performance, assessed by receiver-operating-characteristics (ROC) indexes, evidences fairly good reproduction of the observed event. Comparison with the performance of the traditional debris flow modeling procedure, in which sediment and water hydrographs are inputed as lumped at selected points on top of the streams, are also performed, in order to assess quantitatively the limitations of such com-
\end{abstract}

*Corresponding author: e-mail: lmstanca@dica.unict.it (L.M. Stancanelli) 
monly applied approach. Results show that the proposed method, besides of being more process-consistent than the traditional hydrograph-based approach, can potentially provide a more accurate simulation of debris-flow phenomena, in terms of spatial patterns of erosion and deposition as well on the quantification of mobilized volumes and depths, avoiding debris flow triggering volume overestimation and consequently overestimation of maximum inundation flow depths.

Keywords: susceptibility assessment, debris flow, triggering modeling, propagation modeling, TRIGRS, Giampilieri

\section{Introduction}

Rainfall induced landslides and debris flows are among the most damag-

3 ing natural hazards $[8,45]$. Each year landslides cause thousands of casualties

4 and billions of dollars in damages across the world [17, 14]. Furthermore, un-

5 der certain conditions shallow landslides may evolve into debris flows, causing

6 devastating effects on downstream areas.

7 Effective landslide risk mitigation strategies start from the estimation of de-

8 bris flow susceptibility, i.e. likelihood of debris flow occurrence and the extension

9 of the area potentially affected by propagation and deposition of the mobilized

10 mass. Indeed, susceptibility estimation is an essential step for the assessment

11 of landslide risk and for the identification of appropriate structural and/or non

12 structural mitigation measures. To this end, debris flow triggering and propaga-

13 tion models represent useful tools [21, 19], since they enable to build up reliable

14 inundations maps.

15 Traditional assessment of debris flows propagation requires the definition

16 of an initiation scenario as well as the characterization of the rheology of the

17 moving mass [29]. The former task is generally carried out through the estima-

18 tion of an hydrograph, incremented by a suitable coefficient to account for the

19 solid fraction transported by the debris flow [e.g., 40, 48, 25], or, alternatively,

20 through the definition of an event magnitude based on sediment instability. 
Characterization of the rheology entails the choice of suitable rheological laws, to describe the specific sediment-water mixture subject to movement.

The definition of the event scenario through a hydrograph-based procedure, however, presents two main weak points. First of all, the input is not spatially distributed, since the hydrograph is usually given at some user-defined points. Furthermore, the estimate of the magnitude of the event is often quite uncertain, as it is based on empirical relationship. Thus, the resulting propagation may be affected by significant errors.

On the other hand, various physically based hydrological and slope stability models have been developed to model landslide triggering, also in a spatially distributed fashion $[31,3,4,2,12,20,42,30]$. Such models essentially compute on a DEM basis cells which are likely unstable (and thus can potentially trigger a debris flow) in response to rainfall events, given initial soil moisture conditions. Such models also find application to determine landslide triggering thresholds for early warning $[42,43,37]$.

In this paper, a debris flow susceptibility assessment approach which combines spatially-distributed hydrological model and slope stability analysis with debris flow propagation and deposition models is proposed.

More specifically, the TRIGRS saturated model [3, 4], is combined with FLO2D model for simulating debris flow propagation and deposition [34]. TRIGRS, based on simplifications of the Richards' equation [20] enables to compute the watershed cells subject to geomechanical instability in response to rainfall and has been successfully applied to assess landslide initiation in different case-study areas $[38,37,43,3,4,2,44]$.

Although in principle, use of the outcome of hydrological and slope stability models, namely the potentially unstable cells, as input to propagation models could appear as a straightforward exercise, however this is seldom the case since generally not all of the potentially unstable cells (identified by the triggering models) evolve into landslide and debris flows. In order to overcome such a problem, a topography-based instability-to-debris flow triggering threshold is applied to the output of the TRIGRS model, and the identified triggered cells are 
here used as a spatially-distributed input to the FLO-2D model for simulating debris flow propagation and deposition.

The resulting framework is quite general and is independent from the specific triggering and propagation models adopted. Furthermore, the procedure is in principle more process-consistent than the use of hyper-concentrated hydrographs as input to the FLO-2D model, and may find application also to predict future debris flow initiation and propagation.

The methodology is applied to the well documented debris flow event occurred at Giampilieri (Italy) on 1 October 2009. The results of such application are then compared to those provided by the traditional approach, where the input to the propagation model is as an hyper-concentrated flow hydrograph whose total volumes are those resulting from the application of the TRIGRS and instability-to-debris flow triggering threshold, in order to evaluate uncertainty related to the use of single input points rather that a spatially distributed input.

A comparison of the derived debris flow volumes with those computed by well-known empirical relationships is also carried out, for a more complete assessment of the performance of the rainfall infiltration and geotechnical instability model application.

Paper outline is as follows. In Section 2 the methodology for integrated debris flow susceptibility assessment is illustrated as well as the proposed approach to identify the unstable cells among the potentially unstable ones. Section 3 describes the case-study area and the alluvial event of October $1^{\text {st }}, 2009$, the available data and the debris flow susceptibility assessment, and discusses the results in terms of inundation map, comparing present integrated spatiallydistributed-input approach and the traditional method, and analysing their performance. Finally, Section 4 presents the conclusions and outlooks for further developments. 
To identify the unstable cells of a given catchment, in response to a given rainfall event, we use a model based on the TRIGRS v.1 software $[3,4,2]$. The resulting unstable domain is then filtered to estimate the cells that will likely

85 contribute to debris flow formation (Sect. 2.3).

A sketch of a typical digital terrain model cell used in the computations is shown in Figure 1.

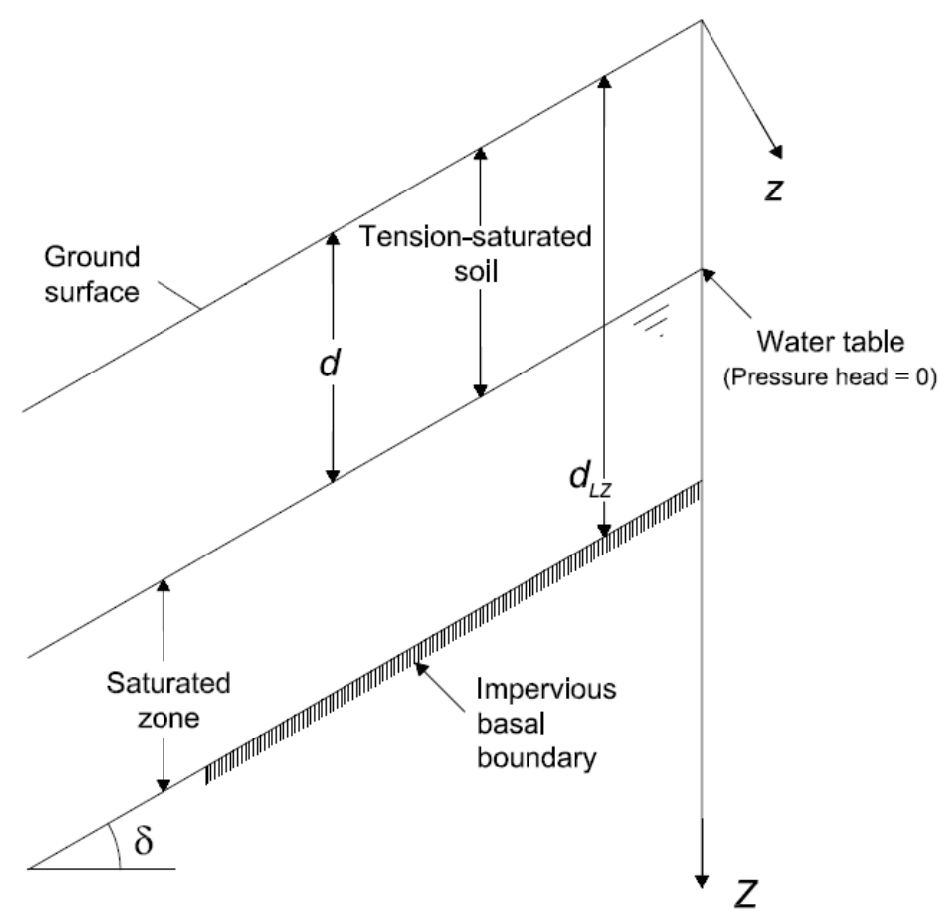

Figure 1: Sketch illustrating the TRIGRS model for pore pressure head and slope stability computation [adapted from 3].

The pressure head $\psi$ at a given depth $Z$ and time instant $t$ of each cell in response to a given rainfall event $I_{n, Z} n=1,2, \ldots, N$, for given initial conditions

90 (i.e., an initial water table depth $d$ ), reads: 


$$
\begin{aligned}
\psi(Z, t)= & (Z-d) \beta+ \\
& 2 \sum_{n=1}^{N} \frac{I_{n Z}}{K_{S}} H\left(t-t_{n}\right)\left[D_{1}\left(t-t_{n}\right)\right]^{1 / 2} . \\
& \sum_{m=1}^{\infty}\left\{\operatorname{ierfc}\left[\frac{(2 m-1) d_{L Z}-\left(d_{L Z}-Z\right)}{2\left[D_{1}\left(t-t_{n}\right)\right]^{1 / 2}}\right]+\operatorname{ierfc}\left[\frac{(2 m-1) d_{L Z}+\left(d_{L Z}-Z\right)}{2\left[D_{1}\left(t-t_{n}\right)\right]^{1 / 2}}\right]\right\}- \\
& 2 \sum_{n=1}^{N} \frac{I_{n Z}}{K_{S}} H\left(t-t_{n+1}\right)\left[D_{1}\left(t-t_{n+1}\right)\right]^{1 / 2} . \\
& \sum_{m=1}^{\infty}\left\{\operatorname{ierfc}\left[\frac{(2 m-1) d_{L Z}-\left(d_{L Z}-Z\right)}{2\left[D_{1}\left(t-t_{n+1}\right)\right]^{1 / 2}}\right]+\operatorname{ierfc}\left[\frac{(2 m-1) d_{L Z}+\left(d_{L Z}-Z\right)}{2\left[D_{1}\left(t-t_{n+1}\right)\right]^{1 / 2}}\right]\right\}
\end{aligned}
$$

where $d_{L Z}$ is the thickness of the permeable soil layer, $K_{S}$ is the saturated hydraulic conductivity, $\beta=\cos ^{2} \delta$, $\delta$ is the terrain slope, $H(\bullet)$ is the Heaviside step function, $D_{1}=D_{0} / \cos ^{2} \delta, D_{0}$ being the saturated soil diffusivity, and $\operatorname{ierfc}(x)=\frac{1}{\sqrt{\pi}} \exp \left(-x^{2}\right)-x \operatorname{erfc}(x)$, erfc being the complementary error function. Pressure head under downward gravity-driven flow cannot exceed that resulting when the water table is at the ground surface [20], namely

$$
\psi(Z, t) \leq Z \beta
$$

One of the main assumption of the model is that the solution presented in Eq. (1) is valid only for tension-saturated initial conditions, so that a linearized version of the Richards equation can be considered to be valid, and the hydraulic conductivity can be approximated by its value at saturation $[20,2]$. It is worth to mention that in our application, no flow routing due to rainfall exceeding infiltration capacity is performed.

After pressure head is computed according to Eqns. (1-2), the factor of safety, which measures the degree of geomechanical stability is computed by the infinite slope formula [51]:

$$
\mathrm{FS}\left(d_{\mathrm{LZ}}, t\right)=\frac{\tan \phi^{\prime}}{\tan \delta}+\frac{c^{\prime}-\psi\left(d_{\mathrm{LZ}}, t\right) \gamma_{\mathrm{w}} \tan \phi^{\prime}}{\gamma_{\mathrm{s}} d_{\mathrm{LZ}} \sin \delta \cos \delta}
$$

where $c^{\prime}$ is soil cohesion for effective stress, $\phi^{\prime}$ is the soil friction angle for effective stress, $\gamma_{\mathrm{w}}$ is the unit weight of groundwater, $\gamma_{\mathrm{s}}$ is the soil unit weight. In the scheme associated with equation 3 the failure occurs at the basal boundary, $Z=d_{L Z}$, since pressure head results maximum at that depth. 


\subsection{Debris flow propagation model}

FLO-2D is a commercial code developed by O'Brien [33], adopted worldwide for modeling debris flow phenomena and delineating flood susceptibility. It is a pseudo two-dimensional model in space, based on depth-integrated flow equations. Hyper-concentrated sediment flows are simulated considering a monophase approach, assuming an empirical quadratic rheological relation [33]. The basic equations implemented in the model consist of the continuity equation:

$$
\frac{\partial h}{\partial t}+\frac{\partial(h V)}{\partial x}=i
$$

and the equation of motion:

$$
S_{f}=S_{o}-\frac{\partial h}{\partial x}-\frac{V}{g} \frac{\partial V}{\partial x}-\frac{1}{g} \frac{\partial V}{\partial t}
$$

where $S_{o}$ is bed slope, $h$ is the flow depth, $V$ is the depth-averaged velocity, $i$ is the excess rainfall intensity (assumed equal to zero in the present application), and $x$ is the generic direction of motion.

In order to solve the momentum equation, FLO-2D considers, for each cell, eight potential flow directions. Each velocity computation is essentially onedimensional and solved independently from the other seven directions, so $h$ and $V$ are related to one of the eight flow directions $x$.

The total friction slope can be expressed as follows:

$$
S_{f}=\frac{\tau_{B}}{\rho g h}+\frac{K \mu_{B} V}{8 \rho g h^{2}}+\frac{n^{2} V^{2}}{h^{\frac{4}{3}}}
$$

where $\tau_{B}$ is the Bingham yield stress, $h$ is the flow depth, $V$ is the mean flow velocity along the flow direction, $\rho$ is mixture density, $K$ is the laminar flow resistance coefficient, $g$ is gravitational acceleration, $\mu_{B}$ is the Bingham viscosity, and $n$ is the pseudo-Manning's resistance coefficient, which accounts for both turbulent boundary friction and internal collisional stresses. In particular, the yield stress $\tau_{B}$, the dynamic viscosity $\mu_{B}$ and the resistance coefficient $n$ are influenced by the sediment concentration and, therefore, can be described by the following equations [34]: 


$$
\begin{gathered}
\tau_{B}=\alpha_{1} e^{\beta_{1} C_{v}} \\
\mu_{B}=\alpha_{2} e^{\beta_{2} C_{v}} \\
n=n_{t} 0.538 e^{6.0896 C_{v}}
\end{gathered}
$$

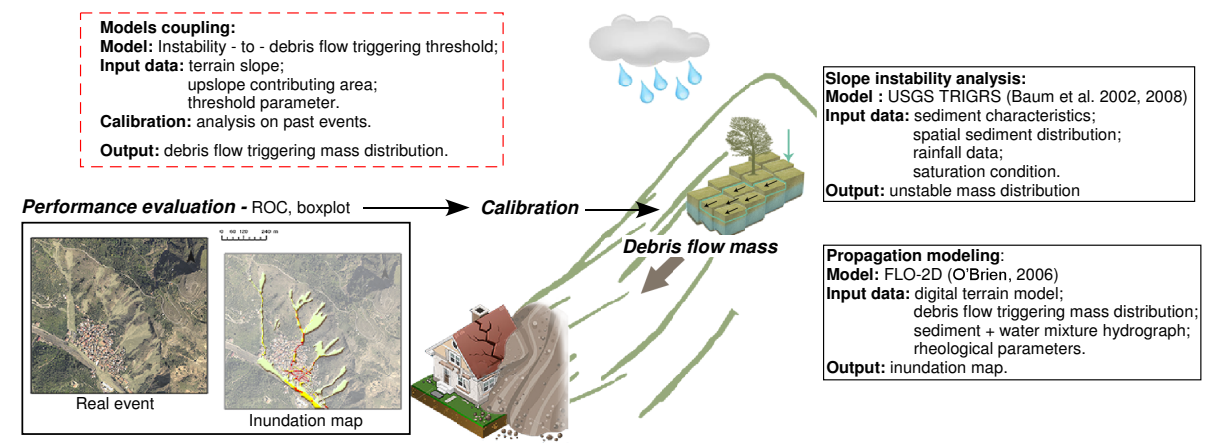

Figure 2: Representative sketch of the different steps and related input data that characterize the proposed methodology.

As already mentioned, a key step of the procedure is the identification of 143 the triggering cells, to be applied as input to the propagation model, among 144 the potentially unstable ones identified through the slope instability analysis. Indeed, such a step is crucial for a proper mass release simulation [26], since 
generally not all the unstable cells move downward as a debris flow. Within the proposed approach the slope stability model is linked to the propagation model by applying a triggering-to-debris flow instability threshold. In particular, once the triggering rainfall event is defined and the soil moisture initial conditions are defined, the cells potentially unstable are computed as those characterized by a factor of safety less than $1(\mathrm{FS} \leq 1)$, thus obtaining the map of potentially unstable cells. Such cells then may take part to two different possible instability triggering phenomena (see Marchi et al. [27]): a) hyper-concentrated flow, b) debris flow generation. The instability-to- debris flow triggering threshold aims at distinguishing the triggering volume involved in these two processes. The unstable cells whose characteristics fall above the threshold propagate as a debris flow, while those below contribute to hyper-concentrated flow. Only the cell that contribute to debris flow formation are inputed to the debris flow routing model (FLO-2D in our case).

In general, whether or not a cell is triggered depends on the sediment characteristics (i.e. mean grain size, permeability, cohesion etc) and sediment spatial distribution (i.e. soil depth variation), as well as the geological characteristics of the catchment (i.e terrain slope) [49]. For an area of given soil properties, the main variables controlling the transition between instability and landslide triggering, are terrain slope $\delta$ and the upslope contributing area $S_{u a}[41,18,36,7]$.

In our work, we slightly modify the instability-to-debris flow triggering threshold for terrain slope $\delta$ proposed by Rickenmann and Zimmermann [41] and others $[18,36,7]$, for extreme debris flow events:

$$
\tan \delta= \begin{cases}0.312 S_{u a} & \text { if } \quad 0.01 \mathrm{~km}^{2} \leq S_{u a}<2.5 \mathrm{~km}^{2} \\ 0.26 & \text { if } \quad S_{u a} \geq 2.5 \mathrm{~km}^{2}\end{cases}
$$

where $S_{u a}$ is the upslope contributing area and $\delta$ the terrain slope.

The instability-to-debris flow triggering threshold may be derived by analysing several debris flow events occurred in a specific area. Here we introduce a parameter in eq. 10 to be calibrated based on observations of real debris flow event, 


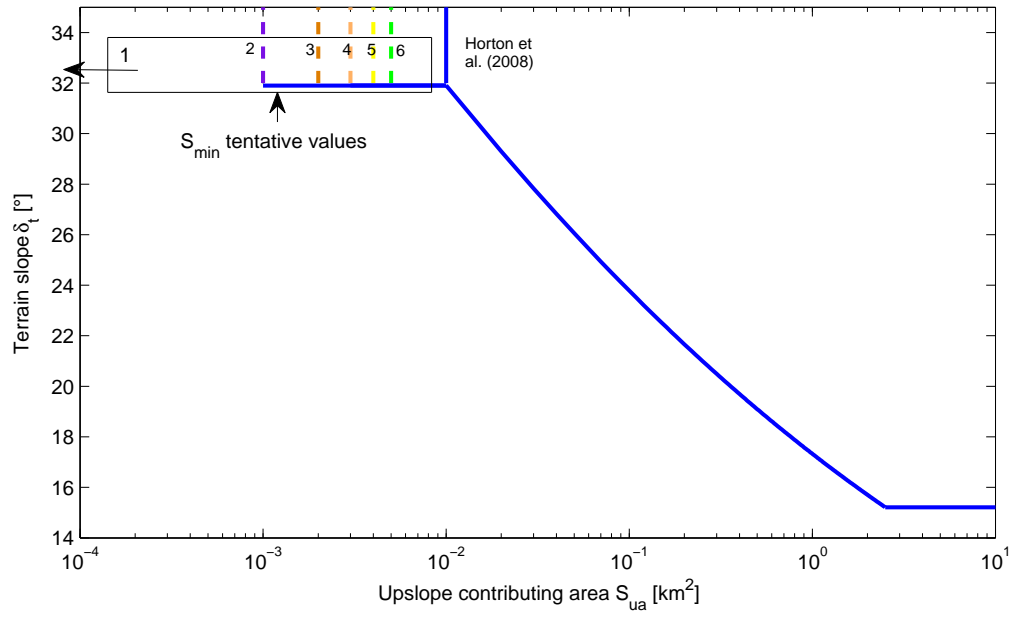

Figure 3: Threshold for deriving debris flow propagating cells from the unstable ones, determined via the TRIGRS Grid-Based Infiltration and Slope stability model. The $S_{\text {min }}$ parameter is to be calibrated, based on comparison with observed debris flow inundation maps and ROC analysis. The values corresponding to the six simulations performed later in Section 3.3 are also indicated in the plot.

maintaining the same functional form. We choose to have just one free parameter since this leads to higher generalization capabilities as well as simplicity. In particular, in the above mentioned studies the most uncertain parameter seems to be the minimum contributing area for initiation. Thus, in order to adapt such instability-to-debris flow triggering threshold in basins characterized by a relatively small area (approximately less than $1 \mathrm{~km}^{2}$ ), we propose the following 179 threshold:

$$
\tan \delta=\left\{\begin{array}{lll}
0.618 & \text { if } \quad S_{\min } \leq S_{u a}<0.01 \mathrm{~km}^{2} \\
0.312 S_{u a}-0.15 & \text { if } \quad 0.01 \mathrm{~km}^{2} \leq S_{u a}<2.5 \mathrm{~km}^{2} \\
0.26 & \text { if } \quad S_{u a} \geq 2.5 \mathrm{~km}^{2}
\end{array}\right.
$$

where the minimum contributing area $S_{\min }$ is calibrated on the basis of observed events (see Figs. 2 and 3).

The calibration of $S_{\min }$ is carried out by searching the value which leads to 
the best reproduction of the observed debris-flow propagation and deposition.

To this end, Receiver Operating Characteristic (ROC) analysis is used to compare the performances of the model for different values of $S_{\min }$. The optimal $S_{\min }$ value can then be potentially used as a reference value for a predictive susceptibility mapping in similar regions, namely in an area characterized by similar geology and rainfall climate. Various ROC indexes can be used to measure the model performance [16]. Suitable indexes are the Equitable Critical Success Index (ECSI), also known as the Equitable Threat Score or Gilbert skill score, and the Heidke skill score (HSS). These indexes are defined as:

$$
\begin{gathered}
E C S I=\frac{T P-T P_{r n d}}{T P+F N+F P-T P_{r n d}} \\
H S S=\frac{T P+T N-E}{T-E}
\end{gathered}
$$

where $T P$ is the number of true positives, $F N$ the number of false negatives, $F P$ the number of false positive, $T=T P+F N+F P+T N, T P_{r n d}=$ $\frac{(T P+F N)(T P+F P)}{T}$ and $E=\frac{1}{T}(T P+F N)(T P+F P)+(T N+F N)(T N+F P)$. In our case, TP is the number of cells where the debris material has deposited both in the field and in simulation; TN is the number of cells where the debris material has not deposited both in the field and in simulation; FP is the number of cells where the debris material has deposited in the simulation but not in the field; FN is the number of cells where the debris material has deposited in the field but not in simulation. The two chosen indexes seems to be among those that suffer less about the limitations of other indexes when the goal is the reproduction of spatial information where the number of Negatives is much higher than the number of Positives, such as in landslide phenomena $[32,16]$.

\section{Application}

\subsection{Case study area}

The analysed area is located in the Peloritani mountains, Sicily, Italy. Specifically we consider debris flow data from the event of 1 October 2009 that hit 
the town of Giampilieri. Giampilieri is a small village located in the South part of Messina Province (Sicily). The historic and most urbanized part of the town is located on the left bank of the Giampilieri river and is mainly settled on slopeland, because of the limited plain area available and the peculiar geomorphologic conditions of the site. The town is crossed by three main tributaries of the Giampilieri river (from West to East: Loco, Sopra Urno and Puntale streams) and others smaller catchments (indicated in Fig. 4 with a reference number). The three main streams drain small watersheds of $0.14 \mathrm{~km}^{2}$ (Loco), $0.07 \mathrm{~km}^{2}$ (Sopra Urno) and $0.03 \mathrm{~km}^{2}$ (Puntale) characterized by narrow valleys (Fig. 4), with elevation ranging approximately between 50 and $400 \mathrm{~m}$ a.s.l., and with a significant proportion of slopes in the interval $30^{\circ}-40^{\circ}$. Soil in the area is composed by highly erodible metamorphic material. The pluviometric regime is that typical of the semiarid areas, with long dry spells during the summer, and high intensity rainstorms of short duration occurring mostly between October and March. The morphology of the small catchments leads to impulsive flash-flood responses. The Peloritani Mountains in general are shaped as several gullies next to each other which induce a high rainfall spatial variability due to orographic effects.

On 1 October 2009, about $250 \mathrm{~mm}$ of rainfall fell in 9 hours, which triggered more than 600 landslides, in an area of $50 \mathrm{~km}^{2}$ of the Messina Province, mostly evolving into devastating debris flows. This event caused the death of 37 persons, about 100 injuries and the evacuation of 1700 residents [15].

Figure 5 shows evidences about slope erosion (see Figure 5a) and damages occurred to the Giampilieri village (Figure 5b-c).

Return period of the rainfall event has been estimated based on observations from the rain gauges in the nearby area in the order of hundreds of years [15]. Although landslide triggering may occur for lower return periods [44], the exceptional magnitude of the event may be also related to a high 15-days antecedent cumulative precipitation, greater than $100 \mathrm{~mm}$, according to measurements of the rain gauge station nearest to Giampilieri in S. Stefano di Briga (see Fig. $6 a)$. 


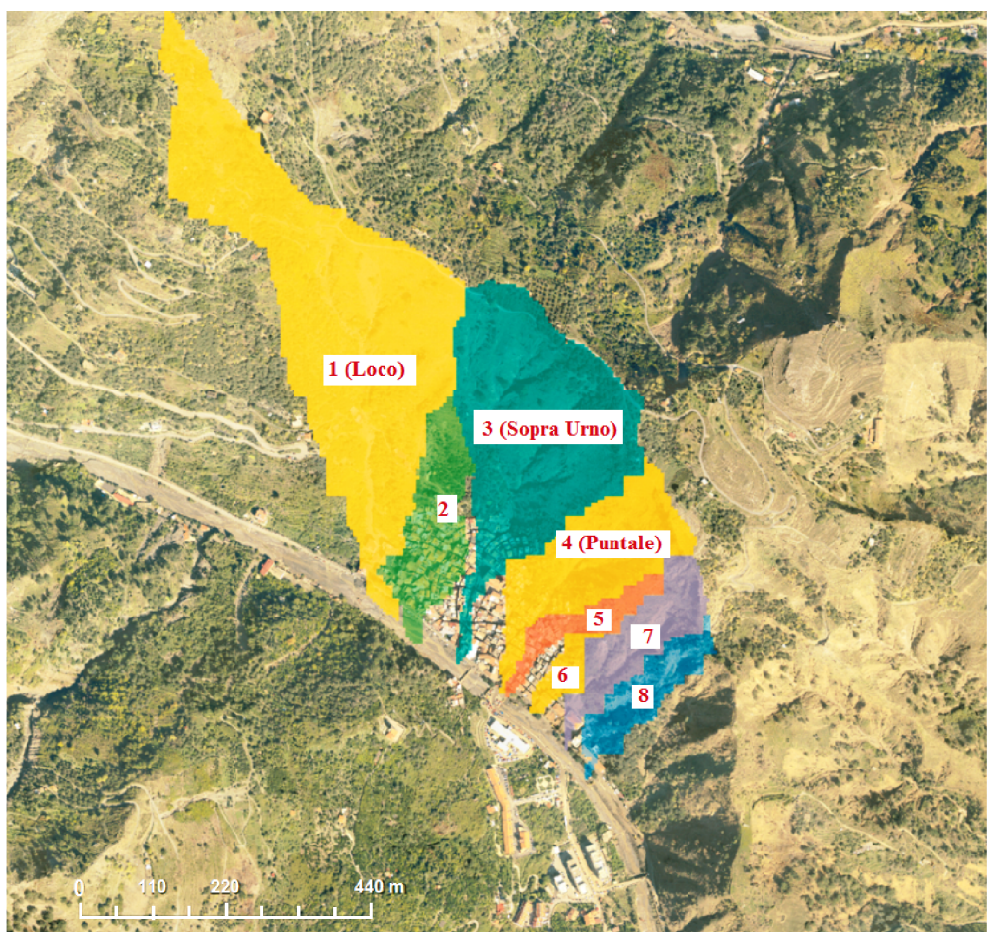

Figure 4: Map showing the creek basins in the analysed area, where basins are numbered from left to right. Nomenclature follows the scientific literature [38, 47, 46].

Cumulative rainfall depths in the period September $5^{\text {th }}-$ October $5^{\text {th }}, 2009$ are shown in the Figure 6a. Such rainfall data were collected by four different stations (Fiumedimisi, S. Stefano di Briga, Messina Istituto Geofisico, Antillo). The Messina Province has been affected by three important rainfall events, occurred on 16th September 2009, 23 $3^{\text {rd }}-24^{\text {th }}$ September 2009 and $1^{\text {st }}$ October 2009. Therefore, the $1^{\text {st }}$ October event it can be assumed that happened when the soil was close to saturated condition. Figure $6 \mathrm{~b}$ shows a detailed representation of rainfall the event of October, $1^{\text {st }} 2009$ by means of the data gathered from rain gauges, showing the high spatial variability of the rainfall event.

The analysis of post event conditions provide useful information about the event development and the consequent damages. Debris flow propagation path presented in Figure 7 affected both the natural slopeland area (defined in the 

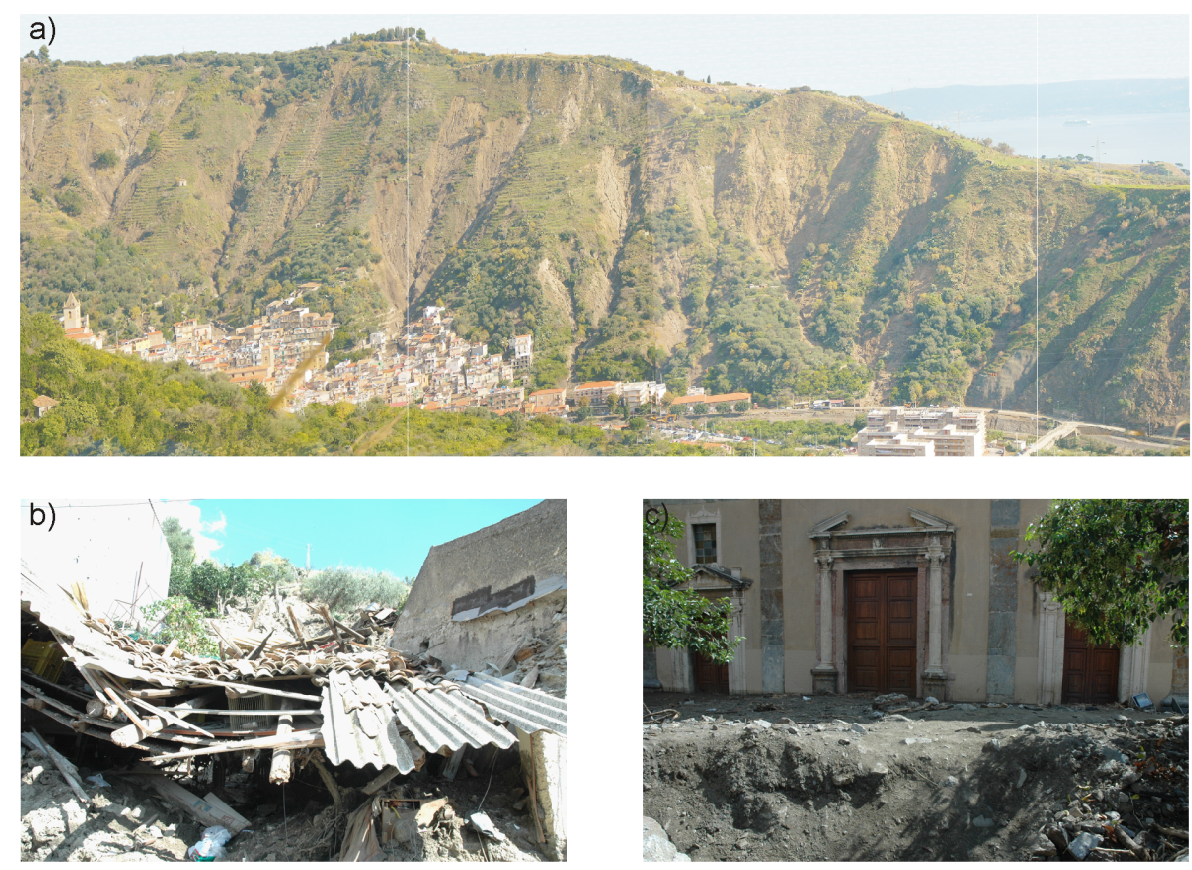

Figure 5: Photo-panorama of Giampilieri village after the alluvial event: a) the slope scoured by debris flows; b) Giampilieri urbanized area damaged by the alluvial event; c) Giampilieri urbanized area where the sediment deposit level is recognizable.

legend as basin) and the urbanized area. Such a distinction will be useful later on for discussing results. Data on sediment deposit level inside the urbanized area are also available (see Figure $7 \mathrm{~b}$ )). This reference map reflects propagation of only debris flow material, and not that of hyperconcentrated flows. Indeed,

the latter component is assumed to exit the area under investigation, because of its relatively low viscosity.

\subsection{Input Data}

The topographic input consist of a digital terrain model (DTM) acquired before the alluvial event of 2009 and characterized by a resolution of $2 \mathrm{~m}$. The DTM has been integrated with information from official maps and orthophotos, concerning the distribution of the buildings. A grid system, with square cells $2 \times 2 \mathrm{~m}$, has been used as a base for modeling processing. Soil proper- 

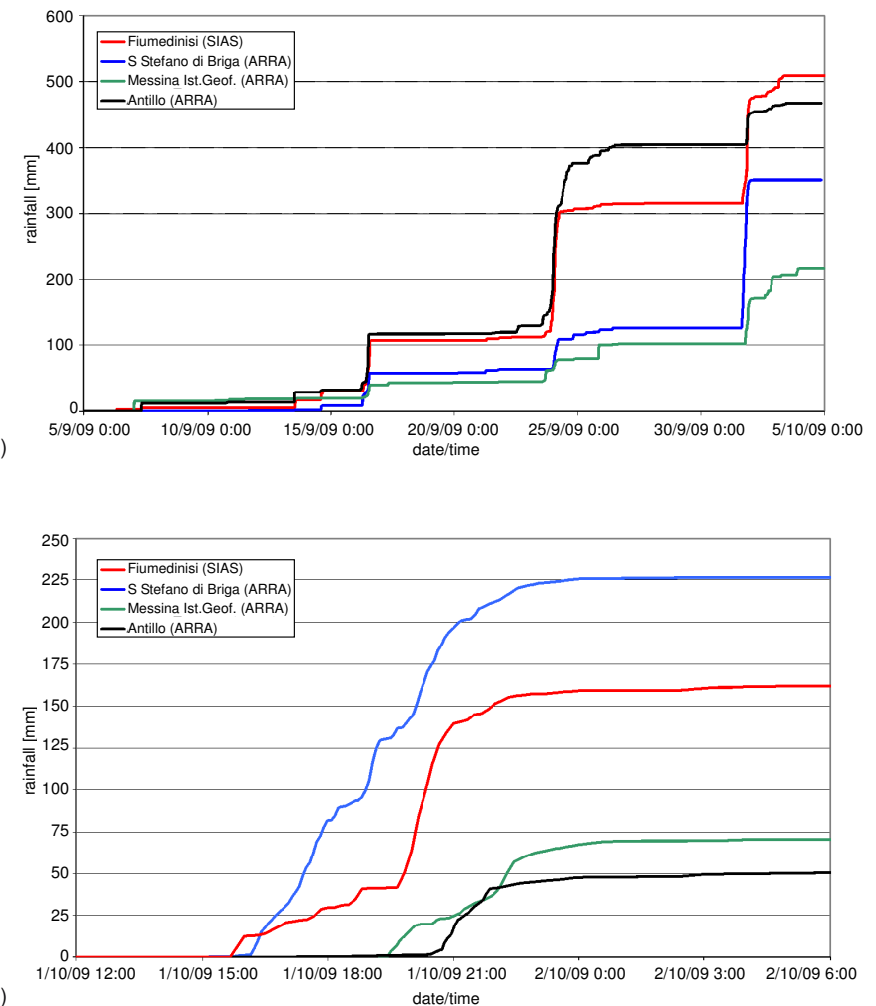

Figure 6: Cumulative rainfall depth data reconstructed from information coming from Fiumedimisi, S. Stefano di Briga, Messina Istituto Geofisico and Antillo stations, for the period ranging: a) from $5^{\text {st }}$ September to $5^{\text {th }}$ October 2009; b) from 12:00 of $1^{\text {st }}$ October 2009 until 6:00 a.m. of $2^{\text {nd }}$ October 2009 .

ties data used to compute unstable cells by means of the TRIGRS model, and globally representative of the Giampilieri area, are summarized in Table 1. Most of the properties are assumed to be constant within the basin, except for soil depth, which has been related to slope using a relationship calibrated on available borehole measurements $d_{L Z}=32 \exp (-0.07 \delta)$ [38]. The limited knowledge of soil proprieties distribution is a problem common to many studies $[31,9,42,43,2,50]$, which explains why constant sediment characteristic along the soil depth are generally assumed in practice. This limit hampers the applica- 


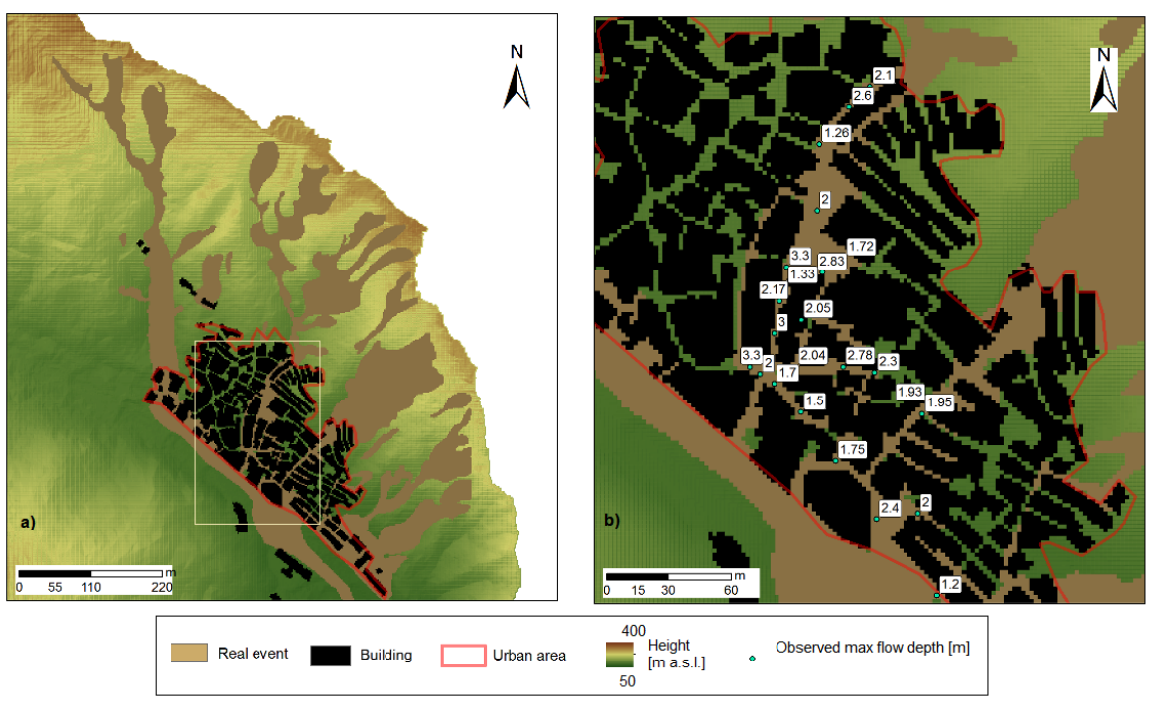

Figure 7: 1 October 2009 maps showing the assumed real event data for model calibration and performance assessment: a) areas affected by landslide-debris-flow phenomena, b) enlargement showing locations and values of observed maximum flow depths in the urbanized area of Giampilieri Village. Maps show the urban area considered in performance assessment for comparison of the performances in such area respect to those on the whole area.

tion of more sophisticated models based on distributed hydrological variables (as soil moisture, lateral water flow, infiltration, streamflow), as the one proposed recently by Anagnostopoulos et al. [1], which includes also analysis of phenomena as solid hydraulic hysteresis and preferential flow increasing the predictive capability. Fan et al. [13], based on the application of a stochastic approach to model the triggering phenomena using soil type and initial water content variation data, indicates that the soil propriety variability could be responsible of an increase of landslide volume. It is worth to point out that among all soil proprieties the spatial distribution of sediment characteristics plays a crucial role on the model predictive ability $[24,11,1]$. Nevertheless, the modeling of soil parameter uncertainties falls beyond the scope of this paper.

Regarding the hydraulic condition, the rainfall time history in different stations back to one month up to the 1 October rainfall event shows a significant 
Table 1: Soil properties data used as input to the TRIGRS model [38].

\begin{tabular}{rrrrrr}
\hline$\phi^{\prime}$ & $c^{\prime}$ & $\gamma_{s}$ & $K_{s}$ & $D_{0}$ & $d_{L Z}$ \\
{$\left[{ }^{\circ}\right]$} & {$[\mathrm{Pa}]$} & {$\left[\mathrm{N} / \mathrm{m}^{2}\right]$} & {$\left[\mathrm{m} / \mathrm{s}^{2}\right]$} & {$\left[\mathrm{m}^{2} / \mathrm{s}\right]$} & {$[\mathrm{m}]$} \\
\hline 39 & 4000 & 19000 & $2 \times 10^{-5}$ & $5 \times 10^{-5}$ & $32 \exp (-0.07 \delta)$ \\
\hline
\end{tabular}

amount of antecedent rainfall (see Figure 6a). This likely allows the use of a tension-saturated model for simulating infiltration processes triggering landslides on 1 October 2009 (see Sect. 2.1). In general, a more precise infiltration model is needed to account for infiltration dynamics in the unsaturated zone considering the soil water characteristic curve, and thus a less simplified version of the Richards' equation (see e.g. [4, 2, 39, 38]). Considering that the rainfall alluvial event was characterized by high spatial variability, our application has been carried out by using the data of Santo Stefano di Briga rainfall gauge station (see Figure 6b), which is the closest to the investigated area and therefore it is considered representative of the 1 October 2009 event in Giampilieri [39]. This rainfall time series has been inputed to the TRIGRS model at an hourly time step. The final instability map corresponding to few hours after the cease of rainfall is used in input to the propagation model FLO-2D, after applying the instability-to-debris-flow-triggering threshold.

Regarding the calibration of the triggering to debris flow threshold (see eq. 11), the debris flow susceptibility maps are obtained considering the total amount of unstable volume defined by the rainfall infiltration and geotechnical instability model, and then those resulting applying Eqn. 11 with the following values of the triggering parameter $S_{\min }$ are assumed: 0.001 ha, 0.002 ha, 0.003 ha, 0.004 ha, 0.005 ha.

Regarding the propagation model, the debris flow phenomena is simulated considering the unstable volume in each grid cell. In light of the soil saturated condition, each single unstable cell volume is transformed in a water-sediment mixture triangular hydrograph characterized by a sediment concentration of 0.5 , with time peak equals to the average basin concentration time (about 6 
minutes). The unstable cells are modeled to be triggered as debris flow at the same instant, the effects of delayed mass release being beyond the scope of this paper. The rheological characteristics of the propagating mixture, such as the yield stress $\tau_{B}$, the dynamic viscosity $\mu_{B}$ and the resistance coefficient $n$, are those determined by Stancanelli and Foti [46], which were obtained through a calibration procedure carried out with reference to the same area considered in this study.

\subsection{Debris flow susceptibility assessment}

Debris flow susceptibility assessment is carried out applying the proposed methodology (indicated in the following as SD "spatially distributed" input) to the Giampilieri area where data of the 1 October 2009 event, described in Sect. 3.2 , are available for calibration and validation.

First, we carried out the slope instability analysis by means of rainfall infiltration and geotechnical instability model (Sect. 2.1). Figure 8 shows the results in terms of instability map applying the TRIGRS model, and considering the six different values of the $S_{\min }$ parameter in Eqn. 11.

From the first instability map of the Fig. 8, the presence of isolated unstable cells can be seen. This is related to the infinite slope assumption in the adopted geotechnical model, for which the failure of each cell is assumed to be independent from the other ones in the catchment. Due to lateral (parallel to the hillslope) forces, real failure generally presents some connectivity, a feature which is better captured by models which include a multi-dimensional analysis of failure [cf. 26, 30, 5, 1], to which our approach may be potentially extended.

The values of $S_{\min }$ adopted in the simulations and the resulting triggered volumes are reported in Table 2. In case of lower and higher $S_{\min }$ the debris flow volume is assumed to have a reduction respectively of $34 \%$ and $67 \%$ of the total triggering volume $\left(S_{\min }=0\right)$.

The landslide-triggering maps are used directly as input to the FLO-2D propagation model; specifically, a hydrograph of volume equal to that of the displaced soil, is associated to each triggered cell. The inundated areas thus 

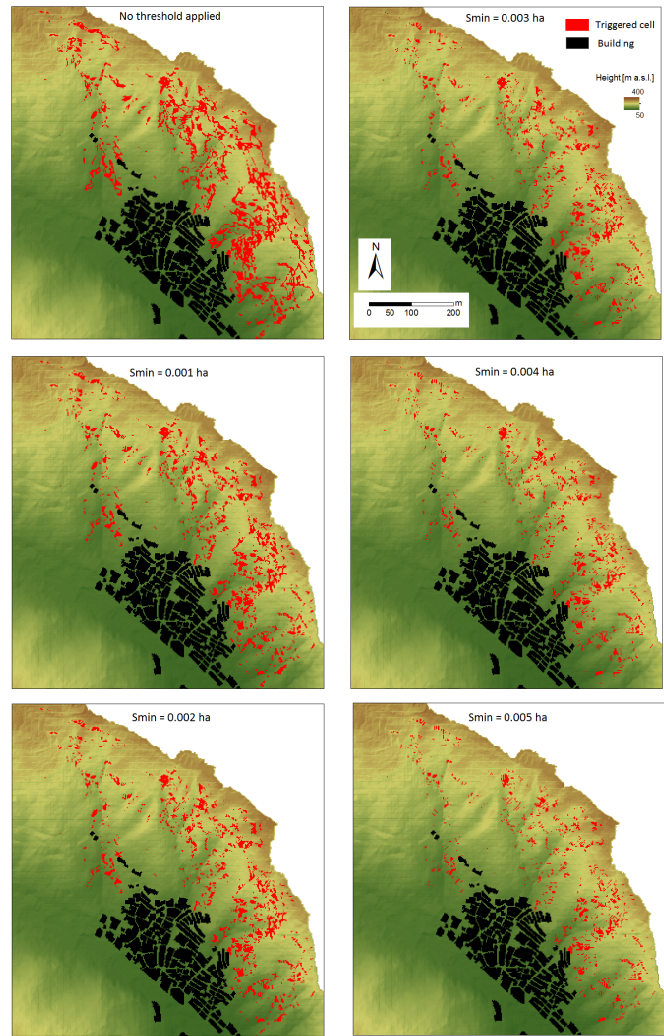

Figure 8: Maps showing the simulated triggered cells for the 1 October 2009 event, obtained by the TRIGRS model and subsequent application of the instability-to-debris-flow-triggering threshold with different values of the $S_{\min }$ parameter, as indicated in the panels. Simulations have been carried out considering as input to the TRIGRS model the hourly-resolution rainfall event measured at the nearest raingauge available (S. Stefano di Briga). 
Table 2: Input triggered volumes, computed by TRIGRS and the specified unstable-totriggering threshold, for each considered basin (see Fig 5a). These volumes have been used as input in the traditional hydrograph-based approach.

\begin{tabular}{lccccccccr}
\hline \multicolumn{10}{c}{ Volume per basin $\left[\mathrm{m}^{3}\right]$} \\
\hline & 1 (Loco) & 2 & 3 (Sopra Urno) & 4 (Puntale) & 5 & 6 & 7 & 8 & Total \\
\hline TRIGRS as-it-is & 11060.8 & 57.9 & 20769.6 & 13814.9 & 1635.4 & 319.4 & 5888.3 & 3969.2 & 57515.5 \\
$S_{\text {min }}=0.001$ ha & 7662.1 & 50.3 & 14272.5 & 9452.1 & 1076.8 & 242.9 & 3182.6 & 2273.0 & 38212.2 \\
$S_{\text {min }}=0.002$ ha & 6513.4 & 42.8 & 12383.2 & 8431.8 & 946.9 & 188.5 & 2623.9 & 1937.2 & 33067.7 \\
$S_{\text {min }}=0.003$ ha & 5055.0 & 29.2 & 9919.2 & 7142.5 & 770.9 & 101.4 & 2053.9 & 1508 & 26580.2 \\
$S_{\text {min }}=0.004$ ha & 4191.0 & 15.3 & 8540.7 & 6459.5 & 684.9 & 81.2 & 1817.3 & 1302.6 & 23092.4 \\
$S_{\text {min }}=0.005$ ha & 3354.8 & 15.3 & 6944.6 & 5649.6 & 547.3 & 40.3 & 1489.3 & 1105.5 & 19146.7 \\
\hline
\end{tabular}

obtained by means of the propagation model are shown in Fig. 9.

The extent of inundation area and the flow-depths (see Figure 9) at the end of the event decreases as higher values of the triggering threshold $S_{\min }$ are applied to the slope instability map.

A few other simulations, emulating the usual procedure of modeling debris flow run-out with the total unstable volumes of debris mixture hydrographs triggered at the top of the sub-basin streams, have also been carried out. We refer to this method as the "traditional" $\mathrm{T}$ one. The aim is to have a reference useful for evaluating the performance of the SD approach proposed here. In particular SD simulations adopted for comparison are those performed with the volumes resulting from the application of the less restricting thresholds, corrisponding to lower values of $S_{\min }$ (case of no threshold, then $\mathrm{Sim}=0.001$ ha and Smin 0.002 ha). The resulting inundation maps are presented in Figure 10.

The spatial distribution of the cells affected by debris flows resulting from the different scenarios is evaluated by comparison with the observed inundation maps, based on the ROC-based indexes of Eqs. 12 and 13 (as shown in Figure 11).

The performances have been assessed separately for the whole domain of simulation (denoted as "basin") and for the urbanized area (indicated as "urban"), which are defined in Fig. 7a.

As it can be inferred from the plots, there is a significant difference between the quality of the reproduction of the real event related to the whole basin 

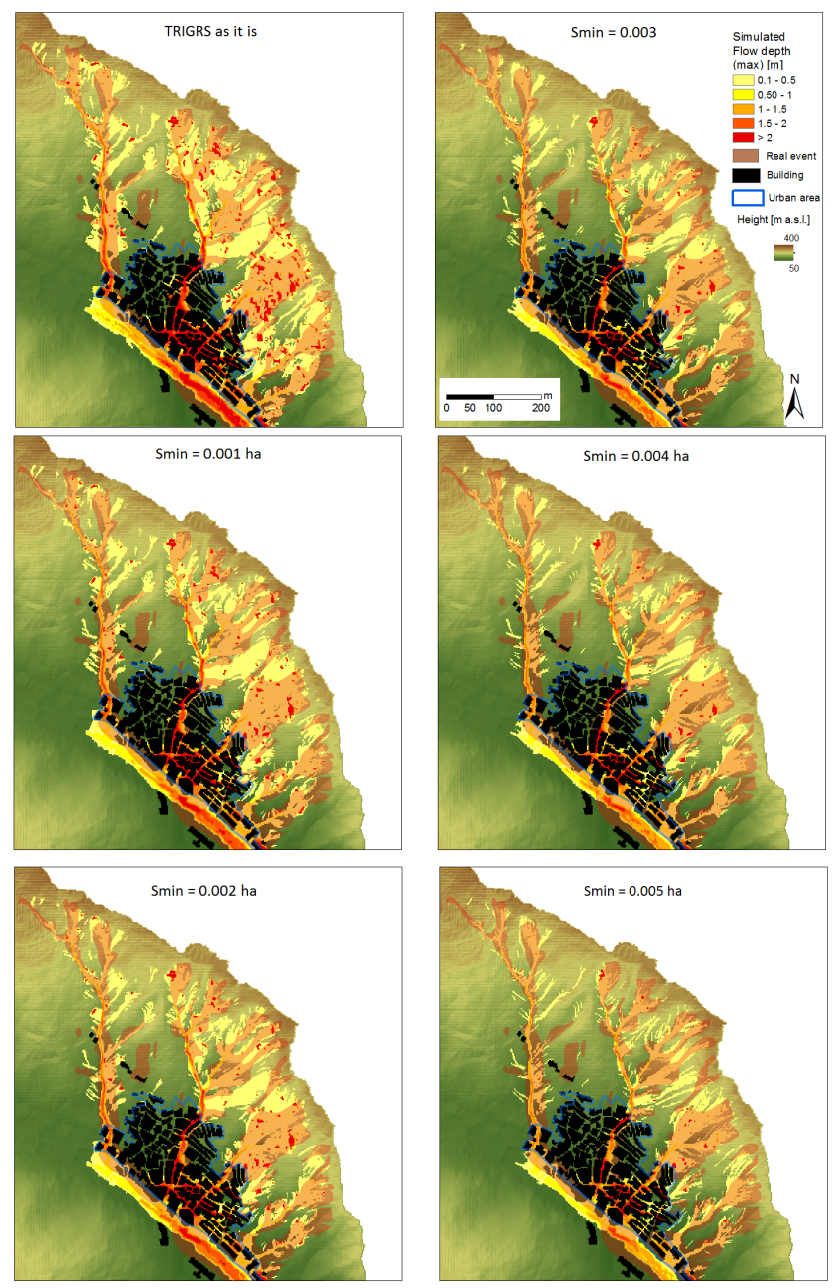

Figure 9: Estimated inundation maps corresponding to different instability-to-debris flow triggering thresholds (Spatially Distributed input: SD). 

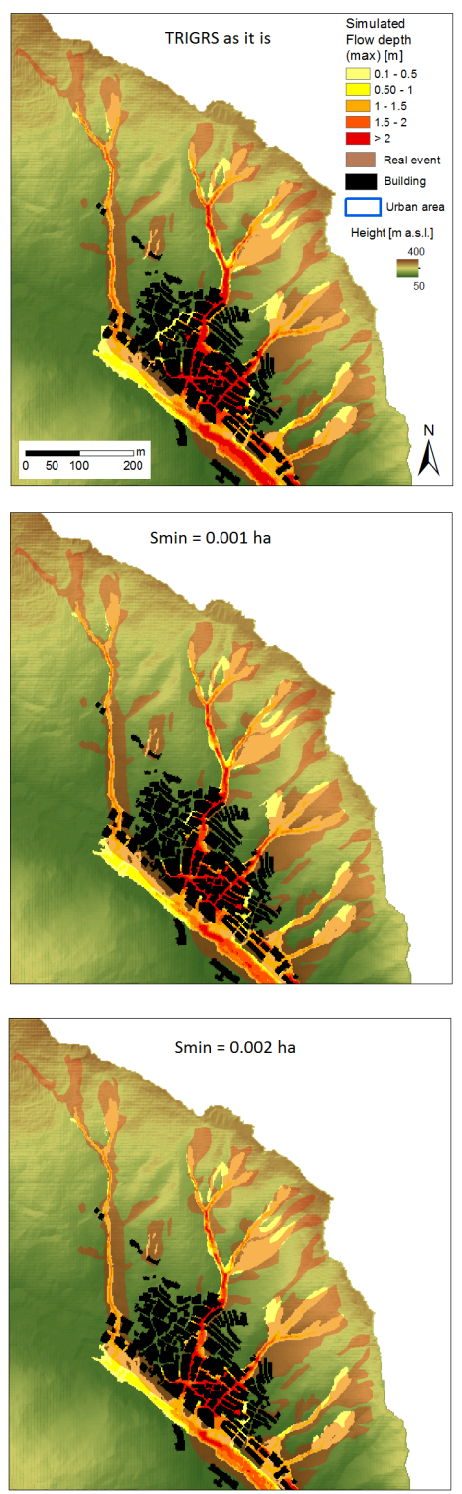

Figure 10: Estimated inundation maps corresponding to different instability-to-debris flow triggering thresholds where inputs are given as lumped hydrographs (Traditional input: T). 


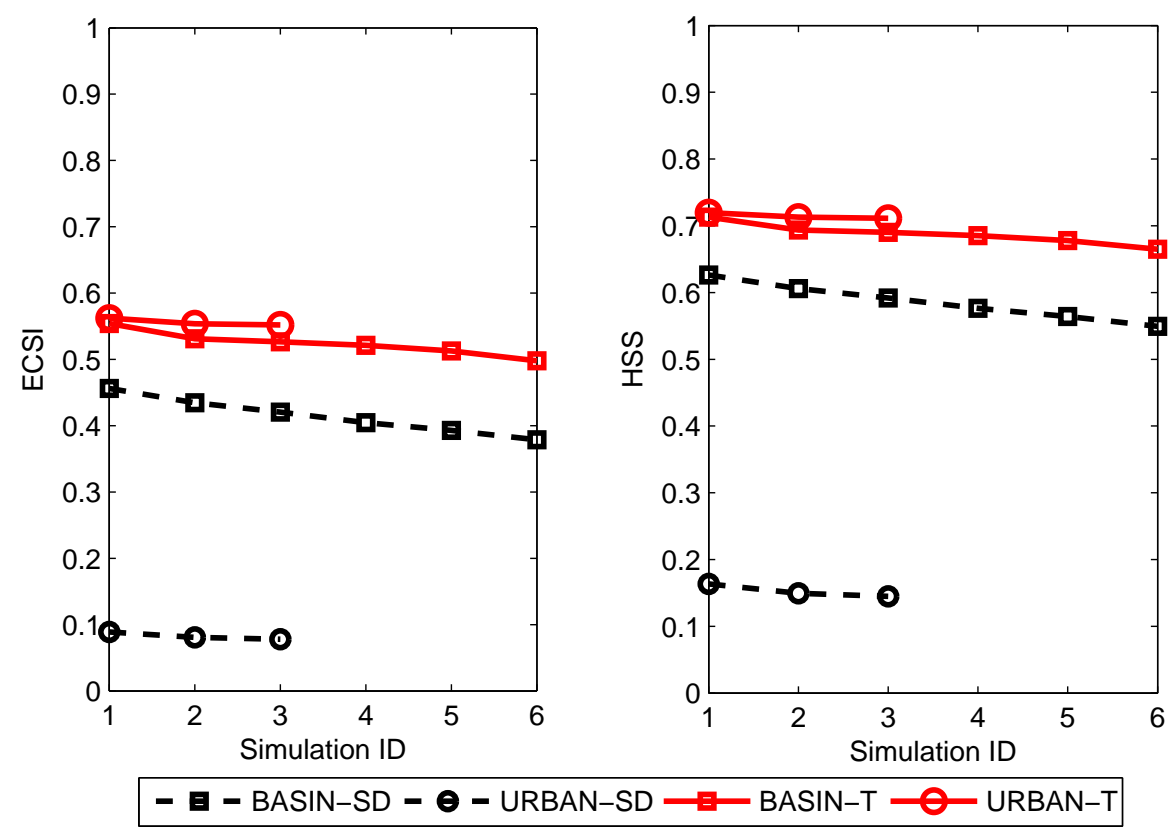

Figure 11: Assessment of model performances in the areal reproduction of the real $1^{\text {st }}$ October event for all six values of the parameter $S_{\min }$ in terms of the Equitable Critical Success Index (ECSI) and the Heidke skill score ROC indexes represented for the basin area and the urbanized area, for the proposed spatially-distributed (SD), and the traditional (T) methodologies. The SIMULATION IDs represent respectively the following: 1. "No threshold", 2. $S_{\min }=0.001 \mathrm{ha}, 3 . S_{\min }=0.002 \mathrm{ha}, 4 . S_{\min }=0.003 \mathrm{ha}, 5 . S_{\min }=0.004 \mathrm{ha}, 6 . S_{\min }=$ 0.005 ha. Though the indexes exhibit only little variations respect to $S_{\min }$, there is a clear difference between performances in the urban area and those in the whole simulation domain. In particular performances in the whole basin are worse than those in the urban area. 
(indicated in black within the figure) and that related to the urbanized area only (red lines), where the model clearly performs better. This highlights that the prediction of triggered areas is a difficult task; in the urban area results are better, but there clearly large margins of improvement (ROC indexes are not higher than 0.8). Lower assessment performance, in case of the entire area, is presumably addressable to assumption of constant sediment characteristics within the basin. Indeed, the latter influences the evaluation of the triggering volume and its distribution on the slopes (basin area). On the other hand, better performance results are obtained within the urbanized area, where factors as DEM accuracy (high in our case) and rheological parameters (previous calibrated in Stancanelli and Foti [46]) play a significant role.

From figure 11, it can be inferred that performances of the SD and T approaches are very similar with respect to the urban area (see red continuous and dotted lines), while with respect to the whole basin area, the former performs significantly better. This reflects the fact that triggered areas are taken into account when specifically assessed by suited models, whereas they are neglected in the case of the traditional hydrograph-based approach. Indeed the better results obtained by the $\mathrm{T}$ approach in the urbanized area are partially due to the reduced heterogeneity and the presence of roads and buildings that limit the possible flow paths.

Regarding the best value of the threshold parameter $S_{\min }$ it can be seen that the differences are quite small, but still it seems that performances decrease as the threshold parameter $S_{\min }$ becomes more restrictive, though it can be stated that the first three simulations are practically equivalent in terms of resulting ROC indexes. In order to better identify which of the three simulations is the best, a comparison between observed and simulated depths at the same point locations has been performed (see Fig. 7); Table 3 shows the related data.

Direct comparison of such depths may not be particularly significant, since it depends on the criteria by which the comparison is carried out. Hence we consider more adequate a coarser assessment, based on the global distribution of debris flow depths in the observation locations, with the aim is to understand 
Table 3: Comparison of maximum flow depths [m] measured and simulated at the specific locations shown in Fig. 7, for both the proposed (spatially distributed) and traditional methodologies.

\begin{tabular}{rrrr|rrr} 
& \multicolumn{3}{c|}{ Spatially distributed method } & \multicolumn{3}{|c}{ Traditional method } \\
\hline Observed & $S_{\min }=0.001$ ha & $S_{\min }=0.002$ ha & $S_{\min }=0.003$ ha & $S_{\min }=0.001$ ha & $S_{\min }=0.002$ ha & $S_{\min }=0.003$ ha \\
\hline 3.30 & 1.94 & 1.86 & 1.74 & 2.89 & 2.17 & 1.96 \\
2.00 & 1.88 & 1.80 & 1.68 & 2.83 & 2.11 & 1.89 \\
3.00 & 5.15 & 5.02 & 4.75 & 6.63 & 5.76 & 5.46 \\
1.70 & 2.11 & 1.96 & 1.67 & 3.16 & 2.41 & 2.17 \\
2.17 & 5.53 & 5.32 & 4.91 & 7.46 & 6.30 & 5.96 \\
3.30 & 3.82 & 3.65 & 3.33 & 5.58 & 4.52 & 4.12 \\
2.04 & 1.58 & 1.44 & 1.20 & 2.55 & 1.90 & 1.69 \\
1.33 & 2.64 & 2.47 & 2.17 & 4.37 & 3.32 & 2.97 \\
2.05 & 0.00 & 0.00 & 0.00 & 0.00 & 0.00 & 0.00 \\
1.50 & 3.08 & 2.81 & 2.35 & 4.90 & 3.70 & 3.29 \\
1.26 & 2.10 & 2.00 & 1.81 & 3.10 & 2.50 & 2.29 \\
2.00 & 1.71 & 1.63 & 1.50 & 2.44 & 1.97 & 1.82 \\
2.83 & 1.50 & 1.33 & 1.02 & 3.20 & 2.13 & 1.76 \\
1.75 & 1.88 & 1.69 & 1.46 & 3.07 & 2.28 & 2.02 \\
1.72 & 0.00 & 0.00 & 0.00 & 0.93 & 0.00 & 0.00 \\
2.78 & 2.60 & 2.46 & 2.21 & 3.61 & 2.99 & 2.74 \\
2.60 & 4.32 & 4.14 & 3.83 & 6.13 & 5.09 & 4.71 \\
2.10 & 3.48 & 3.27 & 2.94 & 5.72 & 4.55 & 4.13 \\
2.30 & 2.65 & 2.49 & 2.23 & 3.67 & 3.01 & 2.81 \\
2.40 & 1.27 & 1.17 & 1.07 & 1.93 & 1.52 & 1.38 \\
2.00 & 1.12 & 1.02 & 0.90 & 1.77 & 1.36 & 1.22 \\
1.95 & 1.56 & 1.51 & 1.37 & 3.13 & 2.45 & 2.25 \\
1.93 & 1.53 & 1.50 & 1.40 & 2.78 & 2.23 & 2.08 \\
1.20 & 0.27 & 0.27 & 0.23 & 0.36 & 0.32 & 0.31 \\
\hline & & & & & \\
& & & & & \\
& & & & & & \\
\end{tabular}

if the model performs globally well in reproducing the magnitudes of the flow depths. The box-plots of Fig. 12 compare the distribution of maximum flow depths, as derived from Table 3.

In particular, for each value of $S_{\min }$ the first box-plots represent the distribution of observed maximum flow-depths on the points where observations were available, and the second one represents that of the simulated flow-depths.

As it can be seen from the box-plots, to apply no instability-to-debris flow triggering filter leads to an over-estimation of the flow-depths. This may be accepted in some applications, if one desires conservativeness of results. Filter of $S_{\min }=0.001$ ha leads indeed to the best results, since $S_{\min }=0.002$ ha is not conservative in this case the median maximum flow-depth, represented by о central line of the box plots, is less than the observed median. 

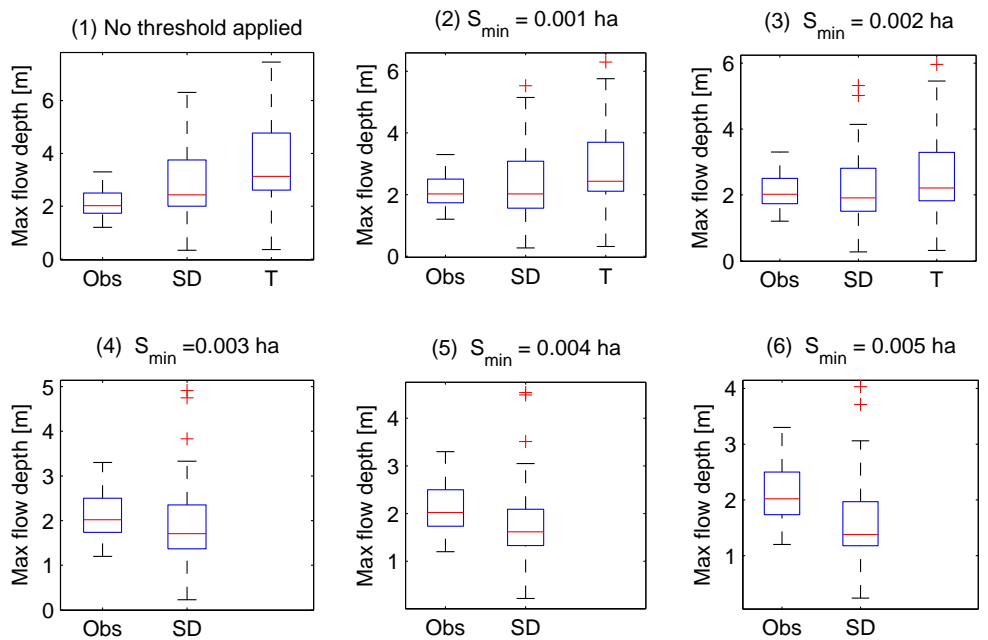

Figure 12: Comparison of the maximum debris flow depth reproduction of the 1 October event for all six scenarios in terms of the box-and-whiskers-plot for the traditional and the proposed spatially-distributed methodology. The box width is equal to the interquartile range and the central value indicates the median value, data outside the whiskers are "out-of-range" values. These plots compare observed-simulated flow depth pairs measured at the same locations, and are obtained from data shown in Table 3. 
The results allow to state that for a susceptibility assessment at the catch-

ment scale the SD approach may be more reliable and conservative, while, in the case that one needs to assess susceptibility in the urbanized area, the traditional approach may still yield reliable results.

Finally, in order to evaluate the performance of the rainfall infiltration and geotechnical instability model in estimating the total eroded volume from the slope and the feasibility of the triggering to debris flow threshold application, the unstable volume have been estimated by commonly-applied empirical formulas and then compared them to those obtained with our methodology (see Tab. 2). Table 4 shows unstable volume estimation for the Loco basin determined applying different approaches, such as: comparison of pre and post event Digital Terrain Model (DTM) [53], output of the TRIGRS modelling, empirical formulations $[6,10,23,28,52]$. It is quite evident that the empirical formulations give only approximate estimations of the possible maximum intensity of slope erodible events [22] and present an high variability. In any case, the results obtained by the proposed methodology suggest that the estimation performed by Ventisette et al. [53] is comparable in dimension $\mathrm{O}\left(10^{4} \mathrm{~m}^{3}\right)$ with the one evaluated by means by means of the physically based slope stability model, when no instability-to-debris flow triggering threshold is applied. The application of the instability-to-debris flow triggering threshold is useful to identify the portion of the total unstable sediment that concurs to the debris flow formation. In case of the alluvial event of 1 October 2009 for the Loco basin, the best simulation (see $S_{\min }=0.001$ ha in Table 2) indicates that an amount of about $31 \%$ of the total sediment unstable volume is eroded as hyperconcentrated flow phenomena. That means that the debris flow that is preceded by a 30 minutes 29 of hyperconcentrated flow, when assuming a solid concentration of 0.2 .

\section{Conclusions}

Modelling debris flow triggering and propagation provides useful tools for susceptibility mapping, an important step for risk mitigation in landslide prone 
Table 4: Unstable volume estimation for the Loco basin using: TRIGRS model, pre-event and post event DEM [53], and several empirical formula [6, 10, 23, 28, 52].

\begin{tabular}{lr}
\hline applied methods & volume $\left[\mathrm{m}^{3}\right]$ \\
\hline TRIGRS model & 11060 \\
Ventisette et al. [53] & 13507 \\
Bianco and Franzi [6] & 3829 \\
Bottino et al. [10] & 12008 \\
Kronfellner-Kraus [23] & 7184 \\
Marchi and Tecca [28] & 9129 \\
Tropeano and Turconi [52] & 83262 \\
\hline
\end{tabular}

areas. Here a methodology for debris-flow modelling is proposed, which couples a spatially distributed map of potential unstable areas and the subsequent propagation and deposition of the triggered masses. To this end, a simple and

general empirical framework for combining triggering and propagation models has been proposed in the paper; the framework is one step toward improving commonly-applied debris flow susceptibility methods, where the triggered mass is estimated by simply incrementing the flood hydrograph by a more or less empirical multiplier that accounts for the presence of the solid phase. The latter approach presents various drawbacks, mainly related to the fact that the destabilized sediment masses are prescribed as input at points chosen empirically and arbitrarily. In addition this lumped approach is strongly basin specific, i.e. depends on the draining basin on which the flood hydrograph is computed.

One crucial step of the proposed methodology is the definition of the landslide instability-to-debris flow triggering threshold, to identify those cells, among the potentially unstable ones resulting from the application of the hydrologicalgeotechnical models, that effectively contribute to debris flow. This threshold may be determined successfully by using data available from past events (inundated areas map and spatial distribution of maximum flow depths). To this 451 aim receiver-operating characteristics (ROC) analysis and statistical tools that 
allow to compare the simulated maximum flow depths with those observed have been used. The calibrated instability-to-debris flow triggering threshold may be used to perform predictive susceptibility mapping in nearby areas that present similar soil hydraulic and geo-mechanical properties. The proposed approach leads to promising results, which may be improved by a multi-parametric optimization and model sensitivity analysis respect to uncertain soil parameter values.

Simulation of the Giampilieri event occurred on 1 October 2009, leads to a generally good agreement with observations. Nonetheless, the procedure still has some limitations, including a) the infinite slope stability analysis on which the TRIGRS model is based generally tends to overestimate unstable cells, because of the neglecting of lateral strength, b) in the FLO-2D model, lack of accounting for erosion processes in high slope region underestimate the volume of the propagation mass. Thus there are still margins of improvement, as suggested by the ROC indexes. The proposed spatially distributed hydrograph approach is found to produce robust and reliable results, especially when assessing susceptibility in the urban area. Moreover, the use of a spatially distributed model for the estimation of the triggered cells, being more consistent with the real process, may lead to better results in the upper parts of the basin where the triggering takes place.

Acknowledgments This research was partially funded by the Italian Education, University and Research Ministry (MIUR), PON project no. 01_01503 Integrated Systems for Hydrogeological Risk Monitoring, Early Warning and Mitigation Along the Main Lifelines, CUP B31H11000370005, and through the Research projects of significant national interest - PRIN 2010-2011 - project name HYDROCAR (cod. 20104J2Y8M_003), and the PRIN 2012 project Project "Hydro-morphodynamics modelling of coastal processes for engineering purposes" (cod. 2012BY_TPR5). The research was also funded by the

European Commission, project HYDRALAB PLUS (proposal number 654110) and through the PO FESR SICILIA 2007 - 2013, Axes IV, Project MedNETNA. All consultants of the OPCM $10^{\text {th }}$ October 2009 no.3815 are greatly acknowl- 
edged for the support demonstrated and for the useful information provided. We would like to thank the Public Civil Engineering Works Office of Messina and the Department of Civil Defence of Sicilian Region for providing important data.

Finally, the authors thank Martin Mergili and other two anonymous reviewers for the useful suggestions and revisions that helped to improve significantly the manuscript.

\section{References}

[1] Anagnostopoulos, G. G., Fatichi, S., Burlando, P., 2015. An advanced process-based distributed model for the investigation of rainfall-induced landslides: The effect of process representation and boundary conditions. Water Resources Research 51 (9), 7501-7523.

[2] Baum, R. L., Godt, J. W., Savage, W. Z., 2010. Estimating the timing and location of shallow rainfall-induced landslides using a model for transient, unsaturated infiltration. Journal of Geophysical Research 115, F03013.

[3] Baum, R. L., Savage, W. Z., Godt, J. W., 2002. TRIGRS - A FORTRAN Program for Transient Rainfall Infiltration and Grid-Based Regional SlopeStability Analysis. U.S. Geological Survey Open-File Report 02-0424, Reston, Virginia.

[4] Baum, R. L., Savage, W. Z., Godt, J. W., 2008. TRIGRS - A FORTRAN program for transient rainfall infiltration and grid-based regional slopestability analysis, version 2.0. U.S. Geological Survey Open-File Report 2008-1159, Reston, Virginia.

[5] Bellugi, D., Milledge, D. G., Dietrich, W. E., McKean, J. A., Perron, J. T., Sudderth, E. B., Kazian, B., 2015. A spectral clustering search algorithm for predicting shallow landslide size and location. Journal of Geophysical Research: Earth Surface 120 (2), 300-324. 
[6] Bianco, G., Franzi, L., 2000. Estimation of debris flow volumes from storm events. In: Proceedings of Debris Flow Mitigation: Mechanics, Prediction and Assessment, Taipei, Taiwan. pp. 441-448.

[7] Blahut, J., Horton, P., Sterlacchini, S., Jaboyedoff, M., 2010. Debris flow hazard modelling on medium scale: Valtellina di tirano, italy. Natural Hazards and Earth System Science 10 (11), 2379-2390.

[8] Bogaard, T. A., Greco, R., 2016. Landslide hydrology: from hydrology to pore pressure. Wiley Interdisciplinary Reviews: Water 3 (3), 439-459.

URL http://dx.doi.org/10.1002/wat2.1126

[9] Borga, M., Dalla Fontana, G., Cazorzi, F., 2002. Analysis of topographic and climatic control on rainfall-triggered shallow landsliding using a quasidynamic wetness index. Journal of Hydrology 268 (1-4), 56-71.

[10] Bottino, G., Crivellari, R., Mandrone, G., 1996. Eventi pluviometrici critici e dissesti: individuazione delle soglie di innesco di colate detritiche nell'anfiteatro morenico di ivrea. In: Proceedings of La prevenzione delle catastrofi idrogeologiche: il contributo alla ricerca scientifica, Alba (Torino). pp. 201-210.

[11] Brönnimann, C., Stähli, M., Schneider, P., Seward, L., Springman, S. M., 2013. Bedrock exfiltration as a triggering mechanism for shallow landslides. Water Resources Research 49 (9), 5155-5167.

URL http://dx.doi.org/10.1002/wrcr. 20386

[12] D’Odorico, P., Fagherazzi, S., Rigon, R., 2005. Potential for landsliding: Dependence on hyetograph characteristics. Journal of Geophysical Research: Earth Surface 110 (F1).

[13] Fan, L., Lehmann, P., Or, D., 2016. Effects of soil spatial variability at the hillslope and catchment scales on characteristics of rainfall-induced landslides. Water Resources Research 52 (3), 1781-1799.

URL http://dx.doi.org/10.1002/2015WR017758 
[14] Farahmand, A., AghaKouchak, A., 2013. A satellite-based global landslide model. Natural Hazards and Earth System Science 13 (5).

[15] Foti, E., Faraci, C., Scandura, P., Cancelliere, A., La Rocca, C., Musumeci, R. E., Nicolosi, V. M., Peres, D., Stancanelli, L. M., 2013. Da giampilieri a saponara: analisi delle cause scatenanti e delle cause predisponenti. ATTI DEI CONVEGNI LINCEI-ACCADEMIA NAZIONALE DEI LINCEI 270, 45-64.

[16] Frattini, P., Crosta, G., Carrara, A., 2010. Techniques for evaluating the performance of landslide susceptibility models. Engineering Geology $111(14), 62-72$.

[17] Highland, L. M., Bobrowsky, P., 2008. The landslide handbook - A guide to understanding landslides. Tech. Rep. 1325, 129 p., U.S. Geological Survey, Reston, Virginia.

[18] Horton, P., Jaboyedoff, M., Rudaz, B., Zimmermann, M., 2013. Flow-r, a model for susceptibility mapping of debris flows and other gravitational hazards at a regional scale. Natural Hazards and Earth System Science $13(4), 869-885$.

[19] Hürlimann, M., Rickenmann, D., Medina, V., Bateman, A., 2008. Evaluation of approaches to calculate debris-flow parameters for hazard assessment. Engineering Geology 102 (3), 152-163.

[20] Iverson, R. M., 2000. Landslide triggering by rain infiltration. Water Resources Research 36, 1897-1910.

[21] Jakob, M., 2005. Debris-flow hazard analysis. In: Debris-flow hazards and related phenomena. Springer, pp. 411-443.

[22] Kritikos, T., Davies, T., 2014. Assessment of rainfall-generated shallow landslide/debris-flow susceptibility and runout using a gis-based approach: application to western southern alps of new zealand. Landslides 12 (6), 
1051-1075.

URL http://dx.doi.org/10.1007/s10346-014-0533-6

[23] Kronfellner-Kraus, G., 1984. Extreme feststofffrachten und grabenbildungen von wildbächen [extreme sediment loads and erosion of torrents]. In: Proceedings of International Symposium Interpraevent. pp. 109-118.

[24] Lanni, C., McDonnell, J., Hopp, L., Rigon, R., 2013. Simulated effect of soil depth and bedrock topography on near-surface hydrologic response and slope stability. Earth Surface Processes and Landforms 38 (2), 146-159.

URL http://dx.doi.org/10.1002/esp.3267

[25] Lanzoni, S., Gregoretti, C., Stancanelli, L. M., 2017. Coarse-grained debris flow dynamics on erodible beds. Journal of Geophysical Research: Earth Surface, n/a-n/a2016JF004046.

URL http://dx.doi.org/10.1002/2016JF004046

[26] Lehmann, P., Or, D., 2012. Hydromechanical triggering of landslides: From progressive local failures to mass release. Water Resources Research 48 (3).

[27] Marchi, L., Arattano, M., Deganutti, A. M., 2002. Ten years of debris-flow monitoring in the moscardo torrent (italian alps). Geomorphology 46 (12), $1-17$.

URL http://www. sciencedirect.com/science/article/pii/S0169555X01001623

[28] Marchi, L., Tecca, P., 1996. Magnitudo delle colate detritiche nelle alpi orientali italiane. Geoingegneria Ambientale e Mineraria 33 (2/3), 79-86.

[29] Mergili, M., Fellin, W., Moreiras, S. M., Stötter, J., 2012. Simulation of debris flows in the central andes based on open source gis: possibilities, limitations, and parameter sensitivity. Natural Hazards 61 (3), 1051-1081.

[30] Milledge, D. G., Bellugi, D., McKean, J. A., Densmore, A. L., Dietrich, W. E., 2014. A multidimensional stability model for predicting shallow landslide size and shape across landscapes. Journal of Geophysical Research: Earth Surface 119 (11), 2481-2504. 
[31] Montgomery, D. R., Dietrich, W. E., 1994. A physically based model for the topographic control on shallow landsliding. Water Resources Research $30,1153-1171$.

[32] Murphy, A., 1996. The finley affair: A signal event in the history of forecast verification. Weather and Forecasting 11 (1), 3-20.

[33] O'Brien, J., 1986. Physical processes, rheology and modeling of mudflows. Doctor of Philosophy dissertation, Colorado State University.

[34] O'Brien, J., 2006. Flo-2d users manual. version 2006.01, flo-2d software. Inc., Nutrioso.

[35] O'Brien, J. S., Julien, P. Y., 1988. Laboratory analysis of mudflow properties. Journal of hydraulic engineering 114 (8), 877-887.

[36] Park, D., Nikhil, N., Lee, S., 2013. Landslide and debris flow susceptibility zonation using trigrs for the 2011 seoul landslide event. Natural Hazards and Earth System Sciences 13 (11), 2833-2849.

[37] Peres, D., Cancelliere, A., 2014. Derivation and evaluation of landslidetriggering thresholds by a monte carlo approach. Hydrology and Earth System Sciences 18 (12), 4913-4931.

[38] Peres, D., Cancelliere, A., 2016. Estimating return period of landslide triggering by monte carlo simulation. Journal of Hydrology, - .

URL http://dx.doi.org/10.1016/j.jhydrol.2016.03.036

[39] Peres, D. J., Cancelliere, A., 2014. Derivation and evaluation of landslidetriggering thresholds by a Monte Carlo approach. Hydrology and Earth System Sciences 18 (12), 4913-4931.

[40] Rickenmann, D., Laigle, D., McArdell, B., Hübl, J., 2006. Comparison of 2d debris-flow simulation models with field events. Computational Geosciences $10(2), 241-264$. 
[41] Rickenmann, D., Zimmermann, M., 1993. The 1987 debris flows in switzerland: documentation and analysis. Geomorphology 8 (2), 175-189.

[42] Rosso, R., Rulli, M. C., Vannucchi, G., 2006. A physically based model for the hydrologic control on shallow landsliding. Water Resources Research $42(6), 1-16$.

[43] Salciarini, D., Godt, J. W., Savage, W. Z., Baum, R. L., Conversini, P., 2008. Modeling landslide recurrence in Seattle, Washington, USA. Engineering Geology 102 (3-4), 227-237.

[44] Schilirò, L., Esposito, C., Scarascia Mugnozza, G., 2015. Evaluation of shallow landslide-triggering scenarios through a physically based approach: an example of application in the southern messina area (northeastern sicily, italy). Natural Hazards and Earth System Science 15 (9), 2091-2109.

[45] Sidle, R. C., Ochiai, H. (Eds.), 2006. Landslides: Processes, Prediction, and Land Use. American Geophysical Union Water Resources Monograph 18. AGU.

[46] Stancanelli, L., Foti, E., 2015. A comparative assessment of two different debris flow propagation approaches-blind simulations on a real debris flow event. Natural Hazards and Earth System Sciences 15 (4), 735-746.

[47] Stancanelli, L., Lanzoni, S., Foti, E., 2014. Mutual interference of two debris flow deposits delivered in a downstream river reach. Journal of Mountain Science 11 (6), 1385-1395.

[48] Stancanelli, L., Lanzoni, S., Foti, E., 2015. Propagation and deposition of stony debris flows at channel confluences. Water Resources Research 51 (7), $5100-5116$.

[49] Takahashi, T., 1981. Estimation of potential debris flows and their hazardous zones: soft countermeasures for a disaster. Natural disaster science 3 (1), 57-89. 
[50] Tarolli, P., Borga, M., Chang, K.-T., Chiang, S.-H., 2011. Modeling shallow landsliding susceptibility by incorporating heavy rainfall statistical properties. Geomorphology 133 (3-4), 199-211.

[51] Taylor, D., 1948. Fundamentals of Soil Mechanics. John Wiley, New York.

[52] Tropeano, D., Turconi, L., 1999. Valutazione del potenziale detritico in piccoli bacini delle Alpi Occidentali e Centrali. CNR-IRPI /GNDCI, Pubbl. n. 2058 Linea 1.

[53] Ventisette, C. D., Garfagnoli, F., Ciampalini, A., Battistini, A., Gigli, G., Moretti, S., Casagli, N., 2012. An integrated approach to the study of catastrophic debris-flows: geological hazard and human influence. Natural Hazards and Earth System Science 12 (9), 2907-2922. 